\title{
EFEK PENAMBAHAN LEVEL VITAMIN E DAN SELENIUM DALAM PAKAN TERHADAP PERFORMA AYAM PETELUR YANG DIINSEMINASI BUATAN
}

\author{
The Effects of Vitamin E and Selenium Level Addition in Feed \\ to Performance of Artificial Insemination Laying Hens
}

\author{
Anna Lidyawati, Binti Khopsoh, Nining Haryuni \\ Department of Animal Husbandry, Faculty of Exact Sciences, Universitas Nahdlatul Ulama Blitar \\ J1. Masjid No. 22, Kota Blitar \\ Email : lidiyawatianna@gmail.com
}

\begin{abstract}
The purpose of this research was to determine the effect of adding vitamin $E$ and selenium as feed additives on the performance of artificially inseminated laying hens. The material used in this research was a 34-week-old laying hen strain of Isa Brown as many as 100 laying hens in artificial insemination. Artificial insemination was done by crossing buras chickens with females from laying hens. Artificial insemination was done every 4 days. This research used statistical analysis using ANOVA with Completely Randomized Design (CRD) which used 5 treatments and 5 replications where each treatment and each replication consisted of 4 laying hens. If there is a real difference or very real influence, it will continued using Duncan's test. The treatment feed in this research are as follows: $P 0=$ Basal Feed, P1 = Basal Feed +21.75 ppm vitamin $E$ and 0.23 ppm selenium, $P 2=$ Basal Feed +43.5 ppm vitamin $E$ and 0.46 ppm selenium, P3 = Basal Feed +65.25 ppm vitamin $E$ and 0.69 ppm selenium, $P 4=$ Basal Feed +87 ppm vitamin $E$ and 0.92 ppm selenium. The results obtained in this research were the addition of vitamin $E$ and selenium in feed had a significant effect $(P<0.05)$ on feed consumption and protein consumption, and also had a very significant effect $(P<0.01)$ on Hen Day Production $(H D P)$ and FCR, but it did not provide significant effect $(P>0.05)$ on egg weight. The best dose addition of vitamin $E$ and selenium is vitamin $E$ by 87 ppm and Selenium by 0.92 ppm.
\end{abstract}

Keywords : Artificial Insemination, Feed Additives, Performance Of Laying Hens, Selenium, Vitamin E

\section{PENDAHULUAN}

Pangan asal ternak merupakan sumber protein hewani yang penting karena kandungan asam-asam amino yang mendekati dari susunan asam amino yang dibutuhkan oleh tubuh manusia sehingga lebih mudah dicerna dan diserap oleh tubuh (Bahri et al., 2005). Unggas merupakan salah satu jenis ternak yang dipelihara untuk menghasilkan daging dan telur. Pengembangan unggas khususnya ayam buras (ayam kampung) masih tergolong rendah karena pada umumnya masih dimanfaatkan sebagai tambahan pendapatan. Disisi lain rendahnya pengembangan usaha ayam buras juga disebabkan rendahnya produktivitas.

Menurut Sutiyono et al., (2006) salah satu cara yang dapat digunakan untuk meningkatkan produktifitas ayam buras adalah menggunakan teknologi reproduksi dengan cara inseminasi buatan (IB). Teknologi inseminasi buatan dapat digunakan untuk memperbaiki mutu genetik ayam dengan melakukan persilangan pada ayam unggul misalnya ayam ras petelur. Teknologi inseminasi buatan dapat digunakan sebagai salah satu terobosan untuk meningkatkan produktivitas ayam buras, akan tetapi muncul permasalahan lain terkait dengan penurunan produksi dari ayam petelur yang diinseminasi buatan karena tingginya tingkat stress yang ditimbulkan pada saat proses inseminasi buatan. Salah satu cara untuk mengurangi penurunan produksi yang disebabkan oleh tingginya tingkat stress pada saat proses inseminasi buatan adalah dengan penambahan vitamin $\mathrm{E}$ dan selenium pada pakan.

Vitamin E dan selenium merupakan antioksidan yang berfungsi untuk melindungi tubuh dari kerusakan akibat radikal bebas. Vitamin E merupakan antioksidan utama dalam sistem biologis yang berperan penting dalam sistem pengaturan metabolisme, melindungi struktur seluler dan menjaga stabilitas membran biologi dari kerusakan dan juga merupakan bagian penting dari reaksi reduksi oksidasi sel (Akil et al., 2009). Kombinasi yang sinergis antara vitamin $\mathrm{E}$ dan selenium berfungsi melindungi jaringan dari kerusakan oksidatif dan dapat meningkatkan respon imun /kekebalan (Lubis et 
$a l ., 2015)$. Hal inilah yang menyebabkan vitamin E dan selenium dapat mengurangi pengaruh negatif yang disebabkan oleh stress (Tamzil, 2014).

\section{MATERI DAN METODE}

\section{Materi}

Penelitian ini menggunakan ayam petelur periode layer strain Isa Brown umur 34 minggu. Ayam petelur yang digunakan adalah sebanyak 100 ekor dengan pakan perlakuan yang digunakan adalah pakan basal yang ditambahkan dengan vitamin $\mathrm{E}$ dan selenium yang telah disesuaikan level pemberiannya.

\section{Metode}

Metode yang digunakan dalam penelitian ini adalah metode eksperimental dengan menggunakan Rancangan Acak Lengkap (RAL) dengan 5 perlakuan dan 5 kali ulangan dengan masing-masing ulangan terdiri dari 4 ekor ayam. Proses inseminasi buatan dalam penelitian ini dilakukan setiap 4 hari sekali dengan level penambahan vitamin E dan selenium sebagai berikut:

$$
\begin{aligned}
& \text { P0 : Pakan Basal } \\
& \text { P1 : Pakan Basal + 21,75 ppm Vitamin E } \\
& \text { dan 0,23 ppm Selenium } \\
& \text { P2 : Pakan Basal + 43,5 ppm Vitamin E } \\
& \text { dan 0,46 ppm Selenium } \\
& \text { P3 : Pakan Basal + 65,25 ppm Vitamin E } \\
& \text { dan 0,69 ppm Selenium }
\end{aligned}
$$
dilakukan tanpa merubah formulasi dari pakan yang digunakan sehingga kandungan nutrisi yang diberikan pada setiap perlakuan sama. Kandungan nutrisi pakan yang digunakan dalam penelitian dapat dilihat pada Tabel 1.

Tabel 1. Analisis proksimat kandungan nutrisi pakan perlakuan

\begin{tabular}{lc}
\hline \multicolumn{1}{c}{ Nutrisi } & Pakan campuran \\
\hline ME $(\mathrm{Kkal} / \mathrm{kg})$ & 2.688 \\
$\mathrm{BK}(\%)$ & 89,30 \\
$\mathrm{PK}(\%)$ & 19,36 \\
LK $(\%)$ & 3,27 \\
SK $(\%)$ & 7,20 \\
\hline Sumber : & Laboratorium Dinas \\
& Peternakan dan
\end{tabular}

\section{Variabel Yang Diamati}

1. Konsumsi pakan

Pengukuran konsumsi pakan dihitung setiap hari dengan satuan $\mathrm{g} / \mathrm{ekor} / \mathrm{hr}$
2. Konsumsi protein

Konsumsi protein dihitung dengan mengalikan jumlah konsumsi pakan dengan kandungan protein pakan

3. Hen Day Production (HDP)

Pengukuran persentase produksi telur dilakukan setiap hari dan kemudian diambil rataan untuk tiap minggunya. Rumus yang digunakan untuk menghitung persentase produksi adalah sebagai berikut :

$$
\mathrm{HDP}=\frac{\sum \text { Produksi telur hari itu (butir) }}{\sum \text { Jumlah ayam yang ada saat itu (ekor) }}
$$

4. Berat telur

Pengambilan data berat telur dilakukan setiap hari dan diambil rataan untuk tiap minggunya.

5. Feed Conversion Ratio (FCR)

Penghitungan konversi pakan dilakukan setiap hari kemudian diambil rataannya untuk tiap minggunya. Nilai konversi pakan bisa didapatkan dengan rumus sebagai berikut :

$$
\mathrm{FCR}=\frac{\sum \text { Konsumsi pakan }(\mathrm{Kg})}{\sum \text { Produksi telur total }(\mathrm{Kg})}
$$

\section{HASIL DAN PEMBAHASAN}

Pengaruh penambahan level vitamin E dan selenium dalam pakan terhadap rataan konsumsi pakan, konsumsi protein, Hen Day Production (HDP), berat telur dan FCR dapat dilihat pada Tabel 2 .

\section{Pengaruh Perlakuan Terhadap Konsumsi Pakan}

Analisis statistik menunjukkan bahwa penambahan vitamin E-selenium dalam pakan memberikan pengaruh yang nyata $(\mathrm{P}<0,05)$ terhadap konsumsi pakan. Rataan konsumsi pakan tertinggi didapatkan pada perlakuan P4 yaitu sebesar $110.496 \mathrm{~g} / \mathrm{ekor} / \mathrm{hari}$.

Perbedaan konsumsi pakan pada penelitian ini disebabkan oleh adanya stres yang merupakan dampak negatif dari kegiatan inseminasi buatan yang dilakukan setiap 4 hari sekali. Ternak yang mengalami stres akan berdampak pada penurunan nafsu makan. Hal ini sesuai dengan Tamzil (2014) yang menyatakan bahwa ternak yang mengalami cekaman menyebabkan stres dan berdampak metabolisme tubuh menjadi tidak normal dan menyebabkan konsumsi pakan menjadi turun. Rataan konsumsi pakan tertinggi didapatkan pada $\mathrm{P} 4$, dikarenakan adanya penambahan vitamin $\mathrm{E}$ dan selenium dengan level yang tinggi pada pakan. Penambahan vitamin E dan selenium ini 
dapat mengurangi tingkat stres pada ayam yang diinseminasi buatan. Hal ini senada dengan pendapat Fauziah et al., (2013) bahwa vitamin E merupakan vitamin yang dapat berfungsi sebagai antioksidan di dalam tubuh ternak dan dapat digunakan untuk mengatasi stres pada ayam.

Tabel 2. Data rataan konsumsi pakan, konsumsi protein, Hen Day Production berat telur dan Feed Consumption Rate

\begin{tabular}{lccccc}
\hline Perlakuan & \multicolumn{5}{c}{ Rataan parameter } \\
\cline { 2 - 5 } & $\begin{array}{c}\text { Konsumsi } \\
\text { pakan } \\
\text { (g/ekor/hari) }\end{array}$ & $\begin{array}{c}\text { Konsumsi } \\
\text { protein } \\
(\text { g/ekor/hari) }\end{array}$ & $\begin{array}{c}\text { Hen Day } \\
\text { Production } \\
(\text { HDP) } \\
(\%)\end{array}$ & $\begin{array}{c}\text { Berat telur } \\
(\mathbf{g})\end{array}$ & $\begin{array}{c}\text { Feed } \\
\text { Consumption } \\
\text { Rate } \\
(\mathbf{F C R})\end{array}$ \\
\hline P0 & $110.296^{\mathrm{a}}$ & $21.356^{\mathrm{a}}$ & $83.348^{\mathrm{a}}$ & $58.852^{\mathrm{a}}$ & $2.2764^{\mathrm{c}}$ \\
P1 & $110.186^{\mathrm{a}}$ & $21.334^{\mathrm{a}}$ & $86.094^{\mathrm{b}}$ & $60.158^{\mathrm{a}}$ & $2.1322^{\mathrm{b}}$ \\
P2 & $110.284^{\mathrm{a}}$ & $21.348^{\mathrm{a}}$ & $86.250^{\mathrm{b}}$ & $60.194^{\mathrm{a}}$ & $2.1300^{\mathrm{b}}$ \\
P3 & $110.486^{\mathrm{a}}$ & $21.370^{\mathrm{a}}$ & $87.510^{\mathrm{c}}$ & $60.144^{\mathrm{a}}$ & $2.1118^{\mathrm{b}}$ \\
P4 & $110.496^{\mathrm{ab}}$ & $21.390^{\mathrm{ab}}$ & $91.424^{\mathrm{d}}$ & $60.210^{\mathrm{a}}$ & $1.9502^{\mathrm{a}}$ \\
\hline
\end{tabular}

Keterangan : Superskrip yang berbeda pada kolom yang sama menunjukkan bahwa perlakuan memberikan pengaruh yang nyata $(\mathrm{P}<0.05)$ pada konsumsi pakan, konsumsi protein dan sangat nyata $(\mathrm{P}<0,01)$ pada Hen Day Production dan FCR pada masing-masing perlakuan.

Faktor yang mempengaruhi konsumsi pakan adalah umur, palatabilitas pakan, energi pakan, tingkat produksi, kuantitas pakan, kualitas pakan, serat kasar, kerapatan jenis atau kepadatan pakan, lemak kasar, galur ayam, bobot badan, bobot telur, penutupan bulu, derajat cekaman dan aktivitas ayam (Amrullah, 2003., Zahra et al., 2012., Allama et al., 2012).

\section{Pengaruh Perlakuan Terhadap Konsumsi Protein}

Analisis statistik menunjukkan bahwa penambahan vitamin E-selenium dalam pakan memberikan pengaruh yang nyata $(\mathrm{P}<0,05)$ terhadap konsumsi protein. Rataan konsumsi protein tertinggi didapatkan pada $\mathrm{P} 4$ yaitu sebesar 21,390 (g/ekor/hari).

Konsumsi protein tertinggi didapatkan pada $\mathrm{P} 4$ disebabkan oleh kandungan protein pada semua pakan perlakuan adalah sama, sehingga konsumsi pakan akan berpengaruh pada konsumsi protein. Pada penelitian ini konsumsi pakan tertinggi adalah pada perlakuan P4 sehingga konsumsi protein yang tertinggi juga pada perlakuan $\mathrm{P} 4$. Hal ini sesuai dengan penelitian yang dilakukan oleh Lubis et al., (2015) peningkatan level vitamin $\mathrm{E}$ dan selenium organik pada itik pegagan menunjukkan konsumsi pakan yang hampir sama namun nilai konsumsi pakan sedikit lebih tinggi jika dibandingkan dengan perlakuan kontrol.

\section{Pengaruh Perlakuan Terhadap Hen Day Production}

Hen Day Production (HDP) merupakan salah satu parameter dari keberhasilan usaha peternakan. Analisis statistik menunjukkan bahwa penambahan vitamin E-selenium dalam pakan memberikan pengaruh yang sangat nyata $(\mathrm{P}<0,01)$ terhadap produksi telur (HDP).

Rataan HDP tertinggi didapatkan pada perlakuan P4 yaitu sebesar 91,424\%. Faktor yang berpengaruh terhadap besarnya produksi telur diantaranya bibit, protein dalam pakan, fosfor, tingkat kedewasan, obat, kesehatan ternak, nutrisi pakan yang sesuai dengan kebutuhan ternak, lingkungan dan pola pemeliharaan(Haryuni et al., 2017,Haryuni, 2018). Faktor lingkungan diantaranya adalah stres yang disebabkan oleh kegiatan inseminasi buatan. Adanya penambahan level vitamin $\mathrm{E}$ dan selenium yang tinggi pada perlakuan P4 dapat mengurangi tingkat stres akibat inseminasi buatan sehingga mempunyai rataan HDP paling tinggi. Hal ini senada dengan penelitian yang dilakukan Lubis et al., (2015) dengan menambahkan vitamin $\mathrm{E}$ dan selenium organik dalam pakan itik pegagan dapat meningkatkan produksi telur.

\section{Pengaruh Perlakuan Terhadap Berat Telur}

Analisis statistik menunjukkan bahwa penambahan vitamin E-selenium dalam pakan memberikan pengaruh yang tidak nyata $(\mathrm{P}>0,05)$ terhadap berat telur. Meskipun secara statistik penambahan level vitamin $\mathrm{E}$ dan selenium tidak memberikan pengaruh yang nyata terhadap berat telur, namun jika dilihat dari besarnya nilai berat telur pada pakan perlakuan yang ditambahkan vitamin $\mathrm{E}$ dan selenium mempunyai berat telur yang lebih besar jika dibandingkan pakan kontrol.

Menurut Mampioper et al., (2008) kualitas pakan yang baik dalam hal ini kandungan protein, asam amino dan asam linoleat akan mempengaruhi bobot telur, karena pakan dengan kualitas yang baik akan menghasilkan telur yang besar. Defisiensi asam amino dapat 
mengakibatkan penurunan produksi dan ukuran telur.

\section{Pengaruh Perlakuan Terhadap Feed Conversion Ratio}

Analisis statistik menunjukkan bahwa penambahan vitamin E-selenium dalam pakan memberikan pengaruh yang sangat nyata $(\mathrm{P}<0,01)$ terhadap Feed Conversion Ratio (FCR). Rataan FCR yang paling kecil terdapat pada $\mathrm{P} 4$ yaitu sebesar 1,9502. Hal ini berkaitan erat dengan HDP dimana HDP yang paling besar didapatkan pada perlakuan P4. Pakan menjadi tidak ekonomis bila nilai konversinya lebih dari dua. Angka konversi pakan tersebut merupakan salah satu kriteria seleksi dalam perbaikan mutu genetik ayam. Faktor yang mempengaruhi konversi pakan adalah bentuk fisik pakan, berat badan ayam, lingkungan pemeliharaan, stres, jenis kelamin (Lokapirnasari et al., 2011)

FCR dapat digunakan untuk menggambarkan besar kecilnya efisiensi pakan dalam suatu usaha peternakan. Semakin kecil nilai FCR maka pakan yang diberikan pada ayam semakin efisien. Nilai FCR juga dapat digunakan untuk dasar menghitung nilai Break Event Point (BEP) harga telur, dengan demikian nilai FCR dapat digunakan untuk dasar menduga keuntungan (Haryuni et al., 2017).

\section{SIMPULAN}

Penambahan level vitamin E dan Selenium memberikan pengaruh yang nyata terhadap konsumsi pakan dan konsumsi protein, berpengaruh sangat nyata terhadap Hen Day Production (HDP) dan FCR, akan tetapi tidak memberikan pengaruh yang nyata terhadap berat telur. Dosis penambahan vitamin E dan selenium yang terbaik adalah vitamin E sebesar 87 ppm dan Selenium sebesar 0,92 ppm.

\section{UCAPAN TERIMA KASIH}

Direktorat Riset dan Pengabdian Masyarakat Kemenristek DIKTI yang telah memberikan dana untuk seluruh rangkaian penelitian.

\section{DAFTAR PUSTAKA}

Akil,S., W.G.Piliang., C.H.Wijaya., D.B.Utomo dan I.K.G.Wiryawan. 2009. Pengkayaan Selenium Organik, Inorganik dan Vitamin E dalam Pakan Puyuh terhadap Performa serta Potensi Telur Puyuh sebagai Sumber Antioksidan. Jurnal Ilmu Ternak Veteriner Vol.14 No.1:1-10.
Allama,H., O.Sofjan, E.Widodo dan H.S.Prayogi. 2012. Pengaruh Penggunaan Tepung Ulat Kandang (Alphitobius diaperinus) Dalam Pakan Terhadap Penampilan Produksi Ayam Pedaging. Jurnal Ilmu-ilmu Peternakan Vol.22 No.3 Hal $1-8$.

Amrulloh, I.K. 2003. Nutrisi Ayam Petelur. Satu Gunung Budi. Bogor.

Bahri,S., E.Masbulan dan N.Kusumaningsih. 2005. Proses Praproduksi Sebagai Faktor Penting Dalam Menghasilkan Produk Ternak Yang Aman Untuk Manusia. Jurnal Litbang Pertanian Vol.24 No.1 Hal 27-35.

Fauziah.A., I. Mangisah dan W. Murningsih. 2013. Pengaruh Penambahan Vitamin E Dan Bakteri AsamLaktat Terhadap Kecernaan Lemak Dan Bobot Telur Ayam Kedu Hitam Dipelihara Secara In Situ. Animal Agricultural Journal Vol.2 No. 1: 319-328.

Haryuni. N. 2018. Analisis Kinerja Finansial Kenaikan Harga Dedak Padi Terhadap Tingkat Pendapatan Peternak Ayam Petelur Di Kabupaten Blitar Jawa Timur. Jurnal Ilmiah Fillia Cendekia Vol. 3 No. 1: $10-15$.

Haryuni. N., E. Widodo dan E. Sudjarwo. 2017. Efek Penambahan Jus dan Daun Sirih (Piper bettle linn) Sebagai Aditif Pakan Terhadap Peforma Ayam Petelur. BRILIANT : Jurnal Riset dan Konseptual Vol. 2 No. 4: 430-434.

Lokapirnasari,W.P., Soewarno dan Y.Damayanti. 2011. Potensi Crude Spirulina Terhadap Protein Effisiensi Rasio pada Ayam Petelur. Jurnal Ilmiah Kedokteran Hewan Vol.2 No.1 Hal 5-8.

Lubis,F.L.N., R. Afianti dan E. Sahara. 2015. Pengaruh Suplementasi Selenium Organik (Se) dan Vitamin E terhadap Performa Itik Pegagan. Jurnal Peternakan Sriwijaya Vol.4 No.1 Hal 28-34.

Mampioper,A., S.D.Rumetor dan F.Pattiselano. 2008. Kualitas Telur Ayam Petelur Yang Mendapat Ransum Perlakuan Subtitusi Jagung Dengan Tepung Singkong. Jurnal Ternak Tropika Vol. 9. No.2 Hal 42-51.

Sutiyono., S. Riyadi dan S. Kismiati. 2006. Fertilitas Dan Daya Tetas Telur Dari Ayam Petelur Hasil Inseminasi Buatan Menggunakan Semen Ayam Kampung Yang Diencerkan Dengan Bahan Berbeda. Jurnal Indonesian Animal Agricutural, Vol.31 No.1 Hal 36-40.

Tamzil, M.H. 2014. Stres Panas pada Unggas: Metabolisme, Akibat dan Upaya Penanggulangannya. Jurnal Wartazoa Vol.24 No.2 Hal 57-66. 
Zahra,A.A., D.Sunarti dan E.Suprijatna. 2012.

Pengaruh Pemberian Pakan BebasPilih

(Free Choice Feeding) Terhadap
Performans Produksi Telur Burung Puyuh (Coturnix coturnix japonica). Animal Agricultural Journal Vol 1 Hal 1-11. 